THE PRIVATE WORLDS OF DYING CHILDREN 



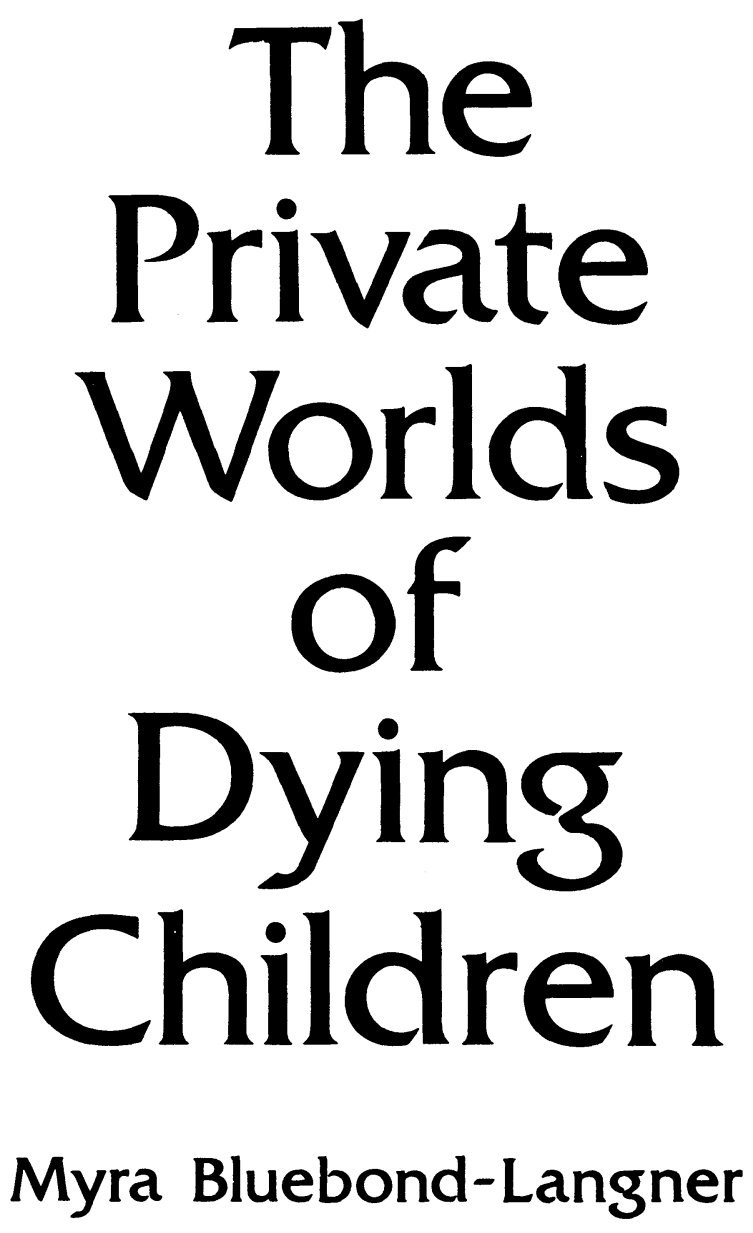

PRINCETON UNIVERSITY PRESS

Princeton, New Jersey 
Copyright (C) 1978 by Princeton University Press

Published by Princeton University Press, Princeton, New Jersey

In the United Kingdom: Princeton University Press,

Chichester, West Sussex

All Rights Reserved

Library of Congress Cataloging-in-Publication Data

Bluebond-Langner, Myra, 1948-

The private worlds of dying children.

Bibliography: $p$.

Includes index.

1. Terminally ill children-Psychology. 2. Socialization.

3. Leukemia in children-Psychological aspects. I. Title.

RJ47.5.B58 618.9'21'55 77-85529

ISBN-13: 978-0-691-02820-0

ISBN-10: 0-691-02820-6

Publication of this book has been aided by a grant from The Andrew W. Mellon Foundation

This book has been composed in Linotype Caledonia

Printed in the United States of America

Princeton University Press books are printed on acid-free paper and meet the guidelines for permanence and durability of the Committee on Production Guidelines for Book Longevity of the Council on Library Resources

Portions of chapters five and six previously appeared as "Meanings of Death to Children," in New Meanings of Death, ed. Herman Feifel, copyright (C) 1977 by McGraw-Hill Book Co.

Part of the appendix appeared as "How I Came to Study Dying Children," in Rhetorical Considerations, ed. Harold Brent and William Lutz, Winthrop Publishers, Inc., 1977.

Most of the final scene in chapter two is quoted from "The Last Day," from Charlotte's Web by E. B. White.

Copyright (C 1952 by E. B. White. Reprinted here by kind permission of Harper \& Row, Publishers, Inc.

First Princeton Paperback printing, 1980 


\section{FOR THE CHILDREN}

“. . . All men struggle against powerful odds to define for themselves a constantly threatened and therefore all the more precious identity within that brief span of time that is their own." (Berger 1963:160) 
